\title{
Revisiting Harmless Discrimination
}

\author{
Tom Parr \\ University of Essex
}

Those who endorse the harm-based account of the wrongness of discrimination hold that 'an instance of discrimination is wrong, when it is, because it makes people worse off'. ${ }^{1}$ In a co-authored piece with Adam Slavny, I pressed two objections against this view. ${ }^{2}$ First, the harm-based account implausibly fails to recognize that harmless discrimination can be wrong. Second, the harm-based account fails to identify all of the wrong-making properties of discriminatory acts. In the light of these failings, we concluded that a more promising account of the wrongness of discrimination must 'focus not only on the harmful outcomes of discriminatory acts but also on the deliberation of the discriminator and in particular on the reasons that motivate or fail to motivate her action'. ${ }^{3}$

In this brief paper, I defend these conclusions against an objection that has recently been pressed against our view by Richard Arneson. ${ }^{4}$ This task is important not only because Arneson's objection is an intriguing one, but also -and more importantly -- because my response sheds further light on the content and structure of an attractive theory of wrongful discrimination, as well as on more fundamental ideas in moral philosophy.

To begin, let's consider the following case:

Law Firm: Marta is an Hispanic female who is applying for positions in law firms. The members of one firm's hiring committee accept her application, but use their contacts to ensure that Marta's application will also be accepted by her first choice law firm, who'll offer her a job on more generous terms. The committee does this because they do not want to work with Hispanic colleagues. Given the generous offer from her first choice employer, and because the committee conceals its motives, Marta is grateful for the intervention. ${ }^{5}$

\footnotetext{
*For helpful discussions about the ideas that appear in this paper, I thank Kasper LippertRasmussen, Adam Slavny, and Victor Tadros.*

${ }^{1}$ Kasper Lippert-Rasmussen, Born Free and Equal: A Philosophical Inquiry into the Nature of Discrimination (Oxford: Oxford University Press, 2014), 154-155.

2 Adam Slavny and Tom Parr, 'Harmless Discrimination', Legal Theory, 21 (2015), 100-114.

${ }^{3}$ Slavny and Parr, 'Harmless Discrimination', 113-114.

${ }^{4}$ Richard Arneson, 'Discrimination and Harm' in Kasper Lippert-Rasmussen (ed.), Routledge Handbook of the Ethics of Discrimination (London: Routledge, 2017), 151-163.

${ }^{5}$ This is a variation of a case described in Arneson, 'Discrimination and Harm', 156-157. See also the case of Cambridge University 3 in Slavny and Parr, 'Harmless Discrimination', 109.
} 
Two features of this case are important: first, Marta is a victim of wrongful discrimination; and second, Marta is not harmed. The upshot of these two facts is that harmless discrimination can be wrong and, because of this, that harm is not the only wrong-making property of discriminatory acts. It is impossible to reconcile these conclusions with the harm-based account, which attempts to explain the wrongness of discrimination exclusively in terms of its harmfulness.

A more promising alternative, I believe, is to incorporate within our account of wrongful discrimination a concern for the deliberations of the discriminator. On this view, an act of discrimination can be wrong in virtue of the bad intentions with which it is performed. This view is well equipped to deal with cases such as Law Firm. After all, Marta is subject to racist prejudice, which is a paradigmatic case of bad intentions.

In response to these arguments, defenders of the harm-based account might attempt to salvage their position by identifying less obvious ways in which Marta is harmed. For example, we might think that Marta suffers a harmful affront to her dignity or that she is a victim of an expressive harm. ${ }^{6}$ In our original paper, we outlined a series of objections to this move, and so I shall therefore set it aside in this paper. ${ }^{7}$

Instead, I shall focus on another objection, which targets the idea that we must incorporate a concern for the deliberations of the discriminator within our account of wrongful discrimination. In characteristic fashion, Arneson illustrates the objection as follows:

Suppose that in the grip of rancorous and hostile emotions, while standing on the sidewalk of busy part of the city, I angrily stick pins in a Justin Bieber doll, expressing my unjustified hostility to him, but knowing this expressive act is harmless. This act might well be stupid, but it seems a long stretch to say it is morally wrong. ${ }^{8}$

Arneson's powerful insight is that acting on bad intentions is not sufficient to establish the wrongness of that act. Some acts -- including some discriminatory acts -- may be morally permissible, even when performed with bad intentions. Instead, he thinks that what matters is whether or not those acts lead to harm: as Arneson puts it, 'the intuition is, no harm, no wrong'. ' If correct, this would

\footnotetext{
${ }^{6}$ For this reply, see D. C. Matthew, 'Counterfactual Discrimination', South African Journal of Philosophy, 36 (2017), 495-504 at 502 fn. 20. See also Arneson, 'Discrimination and Harm', 157 and Shlomi Segall, 'What's so Bad about Discrimination?', Utilitas, 24 (2012), 82-100.

${ }^{7}$ See Slavny and Parr, 'Harmless Discrimination', 106 and 108-109.

${ }^{8}$ Arneson, 'Discrimination and Harm', 157.

${ }^{9}$ Arneson, 'Discrimination and Harm', 157.
} 
provide further support for the harm-based account. (It would also mean that, for Marta to be a victim of wrongful discrimination, there must be some sense in which she is harmed.)

Arneson is surely correct that his case does not involve wrongdoing -- that is, he is correct to hold that it is not wrong angrily to stick pins in a Justin Bieber doll out of unjustified hostility to him. But, this objection misses the mark. This is because we need not claim -- and, in fact, did not claim -- that, in cases of discrimination, acting on bad intentions is sufficient to establish that act's wrongness. ${ }^{10}$ Instead, it is more plausible to maintain that a discriminatory act can be wrong because of its intentions only if there is some probability that the act will affect its target.

This condition is satisfied in Law Firm, where Marta was in fact affected by the firm's hiring committee. This is why we may conclude that the discrimination that Marta suffers is wrong because of the bad intentions of those who reject her application out of racist prejudice. However, the condition is not satisfied in Arneson's case, where there is no probability that angrily sticking pins in the doll will have any effect on Justin Bieber. This is why we may conclude that the act is not wrong.

Though I'll avoid precisely spelling out what it means for there to be some probability that a discriminatory act will have some effect on its victim, three clarifications are helpful. First, the effect need not be harmful. This is the case in Law Firm, where the hiring committee affect Marta, but they do not harm her. It is by incorporating a concern for harmless effects that we can explain how and why harmless discrimination can be wrong.

Second, a discriminatory act may have some effect on its victim, even if that act has no counterfactual effect. This would be the case in Law Firm if Marta would have received identical treatment from another law firm if she' $d$ not been subject to the discrimination that she in fact suffered. In that case, the hiring committee would still wrong Marta, even though their actions would have no counterfactual effect. $^{11}$

Third, in judging whether there is some probability that a discriminatory act will have some effect on its victim, we should distinguish between belief-relative, evidence-relative, and fact-relative probabilities. At the very least, we must

\footnotetext{
${ }^{10}$ Thus Arneson is misunderstands our view when he writes, 'The claim would be that, contra Slavny and Parr, these features of acts [involving bad intentions] are never sufficient to establish their wrongdoing'. See Arneson, 'Discrimination and Harm', 157.

${ }^{11}$ For further discussion, see Victor Tadros, 'Overdetermination and Obligation' (unpublished manuscript).
} 
dispense with the idea that a discriminatory act can be wrong because of its intentions only if there is some fact-relative probability of the act having some effect on its target. ${ }^{12}$ To see this, let's consider a variation on Law Firm, in which the firm's hiring committee decide to discriminate against Marta on racist grounds only if it is sunny on the day of reading her application. As luck would have it, it rains that day, and so the committee choose not to discriminate against Marta. It is intuitive that the committee still wrong Marta even though, given the deterministic laws that govern our weather, there was no fact-relative probability of the act affecting Marta. This case reveals what is unduly restrictive about insisting on there being a fact-relative probability of a discriminatory act having some effect on its target in order to be wrong because of its intentions.

This leaves open the question of which kinds of probabilities matter. My own view is that belief-relative, evidence-relative, and fact-relative probabilities can each be sufficient in these cases. On this view, it can be wrong angrily to stick pins into a Justin Bieber doll, expressing my unjustified hostility to him, under all of the following conditions: (i) when I believe that there is some probability that this will affect him, even though there is no evidence for this belief, and even though this turns out not to be the case; (ii) when there is evidence of there being some probability that this will affect him, even though I do not recognise this evidence, and even though this turns out not to be the case; and (iii) when I do not believe that there is any probability that this will affect him, and when the evidence supports this belief, but it turns out that he is affected. I find it powerfully intuitive that I act wrongly in cases (i)-(iii), though I acknowledge both that others may disagree, and that it is unsatisfactory to rely exclusively on such intuitions in constructing a complete account of the conditions under which an act of discrimination can be wrong because of its intentions. Fortunately, however, it is not necessary to resolve these issues in order to reply to Arneson's objection. Rather, I mention this here merely to draw attention to the relevance of broader philosophical questions to this investigation and to the kind of considerations on which I have relied.

${ }^{12}$ For further discussion, see Tom Parr and Adam Slavny, 'What's Wrong with Risk?' (unpublished manuscript). 